\title{
IMPLEMENTASI PBL UNTUK MENINGKATKAN MOTIVASI, KREATIVITAS DAN PEMAHAMAN KONSEP
}

\author{
Anangga Widya Pradipta, Herminarto Sofyan \\ SD Negeri Nomporejo Galur Kulon Progo, Universitas Negeri Yogyakarta \\ pradiptaanangga@ymail.com, hermin@uny.ac.id
}

\begin{abstract}
Abstrak
Penelitian ini bertujuan untuk meningkatkan motivasi, kreativitas, dan pemahaman konsep ilmu pengetahuan peserta didik melalui implementasi Problem Base Learning (PBL). Jenis penelitian ini adalah penelitian tindakan kelas yang mencakup 4 langkah kegiatan dalam 1 siklus yaitu perencanaan, tindakan, observasi dan refleksi. Subyek penelitian yaitu peserta didik dan guru kelas V SD Negeri Nomporejo pada semester kedua tahun ajaran 2012/2013. Seluruh peserta didik diberi tindakan menggunakan PBL. Data dikumpulkan melalui wawancara, observasi, skala motivasi dan tes. Hasil penelitian ini menunjukkan bahwa penggunaan PBL dapat meningkatkan: (1) motivasi, (2) kreativitas, dan (3) pemahaman konsep peserta didik Kelas V SD Negeri Nomporejo hingga kriteria sangat baik pada siklus III. Aspek motivasi peserta didik meningkat dari rata-rata skor pra-tindakan sebesar 106,25 menjadi 157,95. Aspek kreativitas peserta didik meningkat dari rata-rata skor pra-tindakan 24,25 menjadi 42,6. Aspek pemahaman konsep peserta didik meningkat dari rata-rata skor pra-tindakan 16,5 menjadi 23,65 .
\end{abstract}

Kata Kunci: PBL, motivasi, kreativitas, pemahaman konsep

\section{IMPLEMENTATION OF PBL TO INCREASE MOTIVATION, CREATIVITY AND CONCEPT UNDERSTANDING}

Anangga Widya Pradipta, Herminarto Sofyan

SD Negeri Nomporejo Galur Kulon Progo, Universitas Negeri Yogyakarta

pradiptaanangga@ymail.com, hermin@uny.ac.id

\section{Abstract}

This study aims to improve student's motivation, creativity, and understanding of natural science concepts through the implementation of Problem-Based Learning (PBL). This study was a classroom action research which included 4 steps in 1 cycle: planning, action, observation and reflection. The subject of the study comprised the fifth grade students of State Elementary School Nomporejo Sub-District of Galur, Regency of Kulon Progo. All students were given the treatment of using PBL. Data were collected using interviews, observation, motivation scale and test. Interview techniques was used in the preliminary study. Motivation scale was used to determine the students motivation. The results of the study show that the use of problem-based learning model can improve: (1) motivation, (2) creativity, and (3) concept understanding of the fifth grade students of State Elementary School Nomporejo Sub-District of Galur, Regency of Kulon Progo criteria very well until the third cycle. Aspects of students motivation scores increased from the mean of pre-action 106.25 to 157.95. Aspects of students creativity scores increased from the mean of pre-action 24.25 to 42.6. Aspects of students comprehension of the concept scores increased from the mean of pre-action 16.5 to 23.65.

Keywords: PBL, motivation, creativity, concept comprehension 


\section{Pendahuluan}

Pendidikan memiliki peranan yang penting dalam kehidupan. Pendidikan dianggap penting karena dalam pendidikan merupakan suatu kekuatan yang dinamis dalam kehidupan setiap individu yang mempengaruhi fisik, daya jiwa (akal, rasa dan kehendak), sosial dan moralnya. Kneller dalam Sumitro (2004, p.17) mengemukakan bahwa pendidikan merupakan suatu proses, yaitu pendidikan merujuk pada suatu tindakan atau pengalaman yang mempunyai pengaruh terhadap perkembangan individu (jiwa, watak dan kemampuan fisik), sedangkan dalam arti teknis (hasil) pendidikan dipandang sebagai proses masyarakat melalui lembagalembaga pendidikan formal dengan sengaja mentransformasikan warisan budaya yang berupa pengetahuan, sikap dan keterampilan.

Meninjau pengertian pendidikan yang telah dikemukakan, dalam pendidikan akan terjadi pembelajaran. Pembelajaran yang dimaksud yaitu suatu pembelajaran yang mampu membangun aspek kognitif, afektif, dan psikomotorik peserta didik dalam lingkungan pembelajaran. Proses membangun tersebut dapat terjadi jika peserta didik terlibat aktif dalam pembelajaran dengan menunjukkan motivasi belajar dan didukung kreativitas belajar untuk mencapai pemahaman konsep materi yang dipelajari. Motivasi, kreativitas dan pemahaman konsep dapat terwujud jika peserta didik belajar dalam lingkungan belajar yang sesuai kebutuhan belajar peserta didik. Dewey dalam Arends (2008, p.7) mengemukakan bahwa pendidikan harus mencerminkan masyarakat yang lebih luas dan mencerminkan laboratorium bagi kehidupan nyata.

Motivasi dalam belajar seringkali disebut dengan motivasi belajar. Motivasi belajar sangat diperlukan peserta didik untuk mempelajarai suatu materi pelajaran karena dengan adanya motivasi belajar pada diri peserta didik akan membuat peserta didik terus menerus belajar hingga materi yang dipelajari dapat dipahami. Santrock (2008, p.510) berpendapat bahwa motivasi adalah proses yang memberi semangat, arah, dan kegigihan.

Motivasi belajar yang baik hendaknya juga didukung dengan kreativitas yang baik dalam belajar. Banyak orang mengartikan kreativitas sebagai daya cipta seseorang untuk menciptakan inovasi yang belum ada sama sekali pencetusnya. Sesungguhnya inovasi yang diciptakan bukanlah inovasi yang belum ada sama sekali pencetusnya, tetapi merupakan gabungan inovasi yang sudah ada sebelumnya. Munandar (1990, p.47) berpendapat bahwa kreativitas adalah kemampuan untuk membuat kombinasi baru, berdasarkan data, informasi, atau unsusr-unsur yang ada.

Motivasi dan kreativitas belajar yang baik diharapkan mampu memberikan hasil belajar berupa pemahaman terhadap konsep materi yang dipelajari. Pemahaman terhadap konsep materi yang dipelajari seringkali diartikan sebagai pemahaman konsep. Pemahaman konsep tentang materi yang dipelajari berupa kemampuan menunjukkan ciri khas, menyatakan sifat, menghubungkan, membandingkan dan menjelaskan kembali materi yang telah dipelajari. Bruner dalam Budiningsih (2005, p.43) mengemukakan bahwa seseorang dikatakan memahami suatu konsep jika telah mengetahui semua unsur dari konsep yang meliputi nama, contoh-contoh baik yang posistif maupun yang negatif, karakteristik baik yang pokok maupun yang tidak, rentang karakteristik, dan kaidah.

Pendidikan di Sekolah Dasar merupakan dasar dibentuknya keilmuan dari setiap peserta didik. Keberhasilan dan mutu dari pendidikan di jenjang berikutnya dapat ditentukan dari sekolah dasarnya.

Pada jenjang SD/MI, Ilmu Pengetahuan Alam (IPA) berhubungan dengan cara mencari tahu tentang alam secara sistematis, sehingga IPA bukan hanya penguasaan kumpulan pengetahuan yang berupa fakta-fakta, konsep-konsep, atau prinsip-prinsip saja tetapi juga merupakan 
suatu proses penemuan (KTSP, 2006, p.484). Mengkaji pengertian tersebut, mata pelajaran Ilmu Pengetahuan Alam memiliki materi yang sangat banyak dengan berbagai peristiwa, fakta, konsep dan generalisasi yang harus dikuasai peserta didik, sehingga dalam mempelajari materi tersebut diperlukan motivasi belajar dan kreativitas belajar yang tinggi sehingga pembelajaran dapat berjalan dan memberikan pemahaman konsep yang baik.

Sebagai aktualisasi sifat dari mata pelajaran Ilmu Pengetahuan Alam, beberapa strategi telah dilakukan guru untuk mengatasi permasalahan tersebut. Strategi pertama yaitu dengan memangkas waktu pengajaran teori dan menambah waktu mengerjakan soal-soal, tetapi strategi tersebut menimbulkan masalah baru karena peserta didik kurang menunjukkan motivasi dan kreativitas belajarnya serta kemampuan menjawab soal-soal yang menuntut pemahaman konsep terhadap materi yang dipelajari tidak maksimal. Strategi kedua, yaitu dengan memberikan les tambahan diluar jam pelajaran, namun strategi ini belum mampu mengembangkan motivasi dan kreativitas dalam belajar sehingga berdampak pemahaman konsepnya pun juga masih tergolong rendah.

Berdasarkan observasi pendahuluan dan pemberian pre-test pemahaman konsep Ilmu Pengetahuan Alam kelas V SD Negeri Nomporejo pada tanggal 11 April 2013, diperoleh data bahwa peserta didik telah menunjukkan motivasi belajar, kreativitas belajar telah mencapai taraf cukup, sedangkan pemahaman konsep pada taraf kurang. Tingkat motivasi belajar sebesar 106,25 pada tataran cukup, tingkat kreativitas belajar sebesar 24,25 pada tataran cukup serta tingkat pemahaman konsep sebesar 16,5 butir soal dengan konfersi persentase ketercapaian $58,68 \%$ dari 28 butir soal (masih dibawah KKM yaitu $70 \%)$.

Berdasarkan wawancara dengan peserta didik kelas V SD Negeri Nomporejo diperoleh hasil wawancara bahwa peserta didik mengaku sulit untuk meng- aplikasikan mata pelajaran Ilmu Pengetahun Alam dalam kehidupan nyata. Keadaan ini terjadi sebagai akibat dari rendahnya motivasi dan kreativitas belajar peserta didik. Peserta didik cenderung bersikap pasif dan banyak mengandalkan guru sebagai satu-satunya sumber belajar dan kurang berusaha untuk mencari sumber belajar lain yang relevan untuk mata pelajaran tersebut dikarenakan pengajaran teori disajikan melalui presentasi power point oleh guru, buku teks dan LKS semata, sehingga membuat peserta didik cenderung kurang termotivasi dan kurang memiliki kreativitas belajar dalam menggapai tujuan pembelajaran yang berakibat pada rendahnya pemahaman konsep Ilmu Pengetahuan Alam. Permasalahan lain yang muncul adalah guru hanya menggunakan metode hafalan yang hanya memiliki orientasi keberhasilan pada kemampuan mengingat materi pembelajaran yang banyak, sehingga hanya siswa yang memiliki daya ingat yang tinggi yang mampu meng-ikuti pembelajaran.

Mengkaji permasalahan yang dihadapi, peserta didik kelas V SD Negeri Nomporejo memiliki motivasi belajar, kreativitas belajar dan pemahaman konsep Ilmu Pengetahuan Alam yang perlu ditingkatkan. Peningkatan motivasi belajar, kreativitas belajar dan pemahaman konsep peserta didik memerlukan model pembelajaran yang mampu memfasilitasi perbedaan individu peserta didik. Model pembelajaran merupakan kunci kualitas pembelajaran. Desain model pembelajaran harus sesuai dengan kompetensi yang ingin dicapai. Selain itu, desain model pembelajaran juga harus memperhatikan karakteristik peserta didik, karakter materi dan sumber daya yang dimiliki.

Salah satu usaha untuk meningkatkan motivasi belajar, kreativitas belajar dan pemahaman konsep peserta didik dalam pembelajaran Ilmu Pengetahuan Alam Kelas V SD Negeri Nomporejo adalah penggunaan Model Pembelajaran Berbasis Masalah (Problem Based Learning/PBL). Model pembelajaran ini dalam pelaksanaannya 
mampu mengatasi permasalahan tersebut karena model pembelajaran ini memerlukan motivasi belajar yang tinggi dalam pelaksanaannya dan memerlukan solusi kreatif dalam memecahkan masalah, sehingga peserta didik memperoleh pemahaman konsep terhadap materi yang dipelajari.

Digunakannya PBL pada mata pelajaran Ilmu Pengetahuan Alam memiliki beberapa keunggulan. Keunggulan tersebut lebih mengedepankan pengetahuan awal peserta didik, mengandung kegiatan pengalaman nyata dan bermakna. Keunggulan lain diterapkannya model pembelajaran ini adalah mampu membuat peserta didik terlibat dalam interaksi sosial dan membuat peserta didik peka terhadap lingkungan serta mampu menumbuhkan, menggerakkan, mengarahkan, serta mengorganisasikan perilakunya untuk belajar secara kreatif dalam mencapai tujuan pembelajaran.

Tujuan penelitian yang dilakukan yaitu untuk meningkatkan motivasi belajar, kreativitas belajar, dan pemahaman konsep IPA peserta didik Kelas V SD Negeri Nomporejo melalui implementasi PBL. Hasil penelitian diharapakan dapat memberikan manfaat baik secara teoretis maupun praktis. Manfaat teoretis sebagai upaya pengembangan teori tentang PBL sebagai usaha meningkatkan motivasi belajar, kreativitas belajar dan pemahaman konsep peserta didik. Manfaat praktis bagi guru dapat memberikan konsep penggunaan PBL yang sistematis dalam melaksanakan pembelajaran IPA dan menambah bukti bahwa PBL dapat meningkatkan motivasi belajar, kreativitas belajar dan pemahaman konsep mata pelajaran IPA peserta didik kelas V SD Negeri Nomporejo. Manfaat praktis bagi peserta didik dapat membantu peserta didik untuk mengatasi permasalahan motivasi belajar, kreativitas belajar dan pemahaman konsep IPA peserta didik kelas V SD Negeri Nomporejo sebagai contoh peningkatan kualitas pembelajaran di SD Negeri Nomporejo.
Definisi operasional variabel sebagai berikut: (1) PBL adalah model pembelajaran yang menekankan pada situasi bermasalah yang autentik dan bermakna kepada peserta didik sebagai dasar penyelidikan; (2) motivasi belajar adalah suatu dorongan yang dapat menimbulkan, menggerakkan, mengarahkan, dan mengorganisasikan perilakunya untuk belajar. Aspek intrinsik terdiri dari kemampuan, kebutuhan, minat, keyakinan, tipe tujuan belajar, tipe keterlibatan, keinginan berprestasi, kemungkinan atribusi dan keyakinan tentang kemampuan (Self-Efficacy). Aspek ekstrinsik terdiri dari reward, insentif dan tekanan social; (3) kreativitas belajar adalah suatu kemampuan peserta didik dalam menemukan hubungan-hubungan baru, jawaban, cara baru dalam memecahkan masalah belajar. Ciri-ciri kreativitas belajar terdiri dari dua yaitu ciri kognitif (attitude) dan ciri non-kognitif (non-attitude). Ciri-ciri attitude berhubungan dengan kognisi (proses berfikir) meliputi keterampilan berfikir lancar, keterampilan berfikir luwes, keterampilan berfikir orisinal, keterampilan memerinci, keterampilan menilai. Ciri-ciri non-attitude meliputi rasa ingin tahu, imajinatif, tertantang oleh kemajemukan, berani mengambil resiko dan memiliki sifat menghargai; (4) pemahaman konsep IPA didefinisikan sebagai kemampuan diri dalam mengenal ciri khas, menyatakan sifat, menghubungkan, membandingkan dan menjelaskan kembali Konsep IPA. Konsep IPA dibatasi pada pengetahuan tanah, air dan alam sekitar serta peristiwa alam beserta dampaknya.

\section{Metode Penelitian}

Penelitian ini dilakukan dengan mengkaji situasi sosial dengan maksud untuk meningkatkan motivasi belajar, kreativitas belajar dan pemahaman konsep IPA Kelas V SD Negeri Nomporejo. Berdasarkan penelitian yang dilakukan, penelitian ini menggunakan pendekatan penelitian tindakan (action reseach). Proses dasar penelitian tindakan terdiri dari penyusun- 
an rencana (plan), tindakan (act), observasi (observe) dan refleksi (reflect) tiap siklusnya. Tahapan tersebut dapat diamati pada diagram alir The Action Research Spiral yang disajikan pada Gambar 1.

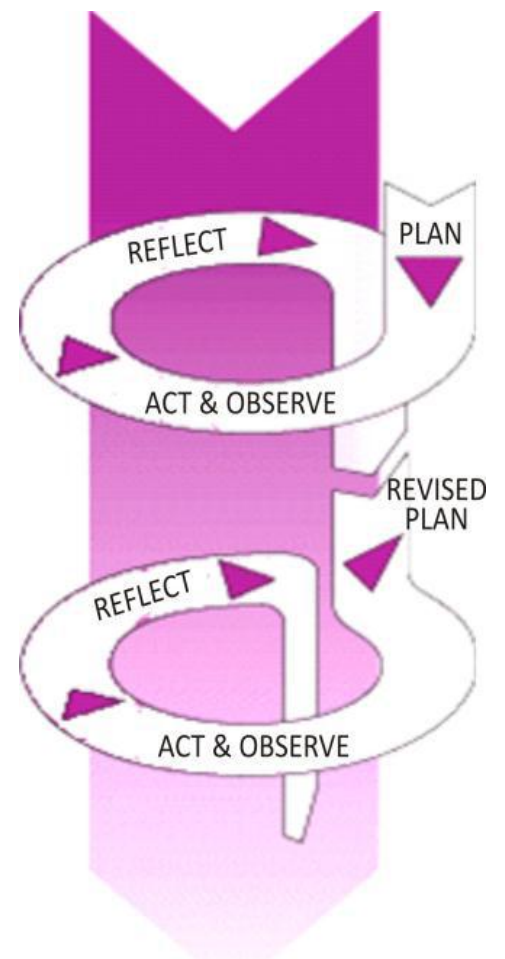

Gambar 1. The Action Research Spiral Kemmis and McTaggart (2000, p.278)

Penelitian tindakan yang dilakukan merupakan penelitian tindakan partisipan. Penelitian ini disebut dengan penelitian partisipan karena peneliti terlibat langsung dalam tindakan yang dilakukan.

Penelitian ini dilaksanakan selama bulan April-Mei 2013. Lokasi penelitian dalam penelitian yaitu SDN nomporejo Galur, Kulon Progo, Yogyakarta. Subyek penelitian ini adalah peserta didik kelas $\mathrm{V}$ SD Negeri Nomporejo berjumlah 20 orang yang terdiri dari 5 peserta didik laki-laki dan 15 peserta didik perempuan. Peserta didik kelas $\mathrm{V}$ merupakan peserta didik yang berusia 10 hingga 12 tahun. Peserta didik usia ini dapat dikatakan telah memiliki cara berfikir maju karena peserta didik sudah mampu menelaah permasalahan meskipun harus diberi gambaran konkret.
Menurut Piaget dalam Budiningsih (2005, p.38) berpendapat bahwa peserta didik kelas V SD masuk dalam tahap operasional konkret dengan ciri pokok anak sudah mulai menggunakan aturan-aturan yang jelas dan logis yang ditandai reversibel dan kekekalan. anak telah memiliki kecakapan berfikir logis tetapi hanya dengan bendabenda yang bersifat konkret, anak sudah dapat berfikir dengan model kemungkinan dan anak dapat menangani sistem klasifikasi.

Dari Hasil pengamatan dan wawancara dalam pembelajaran Ilmu Pengetahuan Alam peserta didik kelas V SD Negeri Nomporejo diperoleh informasi bahwa peserta didik mengaku sulit untuk mengaplikasikan mata pelajaran Ilmu Pengetahun Alam dalam kehidupan nyata. Keadaan ini terjadi sebagai akibat dari kurangnya motivasi dan kreativitas belajar peserta didik. Peserta didik cenderung bersikap pasif dan banyak mengandalkan guru sebagai satu-satunya sumber belajar dan kurang berusaha untuk mencari sumber belajar lain yang relevan untuk mata pelajaran tersebut. Dilain pihak, pengajaran teori disajikan melalui presentasi power point oleh guru, buku teks dan LKS semata, sehingga membuat peserta didik cenderung kurang termotivasi dan kurang memiliki kreativitas belajar dalam menggapai tujuan pembelajaran yang berakibat pada kurangnya pemahaman konsep Ilmu Pengetahuan Alam

\section{Prosedur}

Sebelum melakukan rencana tindakan, terlebih dahulu peneliti melakukan beberapa langkah pra-tindakan agar pelaksanaan tindakan dapat berjalan lancar dan sesuai dengan tujuan penelitian. Pra-Tindakan bertujuan untuk mengetahui permasalahan yang terjadi di kelas, sehingga perlu adanya tindakan kelas untuk memperbaiki permasalahan yang ditemukan. Adapun langkah-langkah Pra-Tindakan terdiri dari: (1) Survey pendahuluan yang dilakukan secara langsung untuk melaku- 
kan pengamatan sebagai penjajagan kemungkinan dan kesediaan sekolah yang bersangkutan untuk dijadikan tempat penelitian; (2) permintaan izin kepada kepala sekolah; (3) mengadakan observasi dan wawacara penelitian kepada kepala sekolah SD Negeri Nomporejo. Wawancara dan observasi bertujuan untuk mendapatkan gambaran keadaan situasi yang ada yaitu dengan melakukan pengamatan pembelajaran yang terjadi di kelas V SD Negeri Nomporejo; (4) mengidentifikasi permasalahan yang terjadi dan menganalisis motivasi belajar, kreativitas belajar serta pemahaman konsep IPA; (5) memberikan penjelasan kepada guru tentang PBL yang sistematis dan sesuai dengan kebutuhan peserta didik; (5) menyusun rencana penelitian. Pada tahap penyusunan rencana penelitian, guru dan peneliti menyusun rangkaian kegiatan secara menyeluruh berupa siklus tindakan kelas menggunakan PBL.

Tindakan merupakan kegiatan pembelajaran yang telah direncanakan. Siklus yang dilakukan meliputi: (1) melakukan observasi untuk mengetahui tingkat motivasi belajar awal, kreativitas belajar awal dan pemahaman konsep IPA awal peserta didik; (2) tindakan yang berupa penerapan PBL yang berupa pemberian orientasi tentang permasalahan kepada peserta didik, mengorganisasi peserta didik untuk meneliti, membantu investigasi mandiri dan kelompok, mengembangkan serta mempresentasikan hasil dan menganalisis dan mengevaluasi proses; (3) observasi dilakukan oleh peneliti dibantu satu orang pengamat dengan tujuan mengamati motivasi belajar, kreativitas belajar dan pemahaman konsep peserta didik dalam pembelajaran Ilmu Pengetahuan pada pokok bahasan bumi dan alam semesta menggunakan PBL; (4) Refleksi yang dilakukan untuk melihat proses dan untuk mengetahui kendala selama proses tindakan kegiatan ini meliputi mendeskripsikan penerapan PBL terhadap motivasi belajar, kreativitas belajar dan pemahaman konsep serta mencari permasalahan yang muncul dalam satu siklus sebagai dasar tindakan siklus berikutnya.

Instrumen penelitian terdiri dari lembar skala pengukuran motivasi, pedoman observasi kreativitas belajar, dan tes pemahaman konsep IPA. Teknik dalam pengumpulan data, teknik tersebut antara lain sebagai berikut: (1) wawancara untuk menggali permasalahan yang ada dalam pembelajaran, yaitu dilakukan saat studi pendahuluan serta mengetahui hambatan dalam pembelajaran selama siklus tindakan menggunakan PBL menggunakan teknik wawancara tidak terstruktur; (2) skala Pengukuran untuk mengukur sikap peserta didik yang menunjukkan motivasi belajar sehingga disebut skala motivasi; (3) observasi digunakan untuk mengamati kegiatan pembelajaran Mata Pelajaran IPA menggunakan PBL, mengamati dan mencatat perilaku yang menunjukkan kreativitas belajar, mengetahui situasi rumit dan halangan serta mengetahui masalah yang dikenakan tindakan yaitu motivasi belajar, kreativitas belajar dan pemahaman konsep IPA peserta didik; (4) tes digunakan untuk memperoleh data mengenai pemahaman konsep IPA.

Suatu instrumen haruslah mempunyai ketepatan dan kecermatan dalam melakukan fungsi ukurannya (Sugiyono, 201, p.168). Dalam penelitian yang dilakukan, peneliti menggunakan judgement expert, uji validitas konstruk dan validitas isi. Pelaksanaan Uji Validitas Instrumen. Uji Validitas lembar angket motivas belajar dan kreativitas belajar Ilmu Pengetahuan Alam dilakukan dengan jenis pengujian judgement expert, yaitu memohon ahli validasi yang berkompeten untuk memberikan validitas butir instrumen, yaitu: Dr. Suwarjo M. Si. Uji Validitas Tes Pemahaman Konsep Ilmu Pengetahuan Alam dilakukan dengan jenis pengujian validitas isi. Pengujian validitas isi dilakukan dengan judgement expert, yaitu memohon ahli validasi yang berkompeten untuk memberikan rekomendasi butir instrumen yaitu Woro Dwi Hastuti M.Pd. Hasil judgement expert dianalisis statistik menggunakan 
korelasi product moment dalam Sugiyono (2003, p.213) dan dianalisis menggunakan software ITEMAN.

$$
r_{x y}=\frac{N \sum X Y-\left(\sum X\right)\left(\sum Y\right)}{\sqrt{\left\{N \sum X^{2}-\left(\sum X^{2}\right)\right\}\left\{N \sum Y^{2}-\left(\sum Y^{2}\right)\right\}}}
$$

Keputusan uji:

Bila $\mathrm{r}$ hitung $>\mathrm{r}$ teori instrument dinyatakan valid (diterima). Bila $r$ hitung $<\mathrm{r}$ teori instrument tidak valid (ditolak)

Stainback dalam Sugiyono (2012, p.362) menyatakan bahwa reliabilitas berkenaan dengan derajat konsistensi dan stabilitas data temuan. Salah satu cara untuk mengetahui data reliabel, dalam penelitian tindakan kelas dapat dilakukan dengan mempercayai penilaian peneliti itu sendiri. Berdasarkan pendapat yang telah dikemukakan ahli tentang reliabilitas, maka salah satu cara untuk meyakinkan tingkat reliabilitas data dilakukan dengan sajian data asli, seperti hasil observasi, angket, dan tes pemahaman konsep. Berdasarkan pendapat tersebut maka reliabilitas instrument dilakukan menggunakan sajian data asli. Khusus untuk test pemahaman konsep Ilmu Pengetahuan Alam dianalisis secara statistik. Reliabilitas instrumen pemahaman konsep dilakukan dengan teknik nonbelah dua yang dikembangkan oleh Kuder dan Richardson yaitu formula KR-20 dalam Sugiyono (2012, p.180)

$$
r_{11}=\left(\frac{n}{n-1}\right)\left(\frac{s^{2}-\sum p q}{S^{2}}\right)=
$$

Keterangan:

R11 : reliabilitas tes secara keseluruhan.

$\mathrm{p}$ : proporsi subjek yang menjawab benar butir soal ke-i.

q : proporsi subjek yang menjawab salah butir soal ke-I $(q=1-p)$.

$\sum$ pq: jumlah hasil kali p dan q.

$\mathrm{n}$ : banyaknya item.

S : standar deviasi (akar varians)
Teknik Analisis Data

Data yang diperoleh dianalisis menggunakan teknik analisis data statistik deskriptif melalui tabel, diagram, penyajian rerata serta perhitungan persentase pencapaian motivasi belajar, kreativitas belajar dan pemahaman konsep tiap siklusnya. Hasil analisis data deskriptif kuantitatif kemudian dimaknai secara kualitatif menggunakan kriteria kategori penilaian ideal melalui konversi skor 5 skala. Kriteria kategori penilaian ideal disajikan pada Tabel 1.

Tabel 1. Kriteria Kategori Penilaian Ideal

\begin{tabular}{cc}
\hline Kriteria & Skor \\
\hline Sangat Baik & mean $X_{i}+1,80 S B_{i}<\mathrm{X}$ \\
Baik & mean $\mathrm{X}_{i}+0,60 S B_{i}<\mathrm{X} \leq$ mean $\mathrm{X}_{i}+1,80 S B_{i}$ \\
Cukup & mean $\mathrm{X}_{i}-0,60 S B_{i}<\mathrm{X} \leq$ mean $\mathrm{X}_{i}+0,60 S B_{i}$ \\
Kurang & mean $\mathrm{X}_{i}-1,80 S B_{i}<\mathrm{X} \leq$ mean $\mathrm{X}_{i}-0,60 S B_{i}$ \\
Sangat & $\mathrm{X} \leq$ mean $\mathrm{X}_{i}-1,80 S B_{i}$ \\
Kurang & \\
\hline
\end{tabular}

Sumber: Kumpulan Materi Evaluasi

Pembelajaran, Sukardjo (2006, p.53)

Keterangan:

mean $_{i}$ : rerata skor ideal,

$S B_{i} \quad$ : simpangan baku skor ideal

$X \quad$ : skor aktual

Berdasarkan kriteria kategori penilaian ideal tabel 1, maka hasil observasi dan pre-Tes pratindakan dapat disusun tabel klas interval untuk kriteria penilaian ideal variabel motivasi belajar, kreativitas belajar dan pemahaman konsep pada Tabel 2, Tabel 3 dan Tabel 4.

Tabel 2. Kriteria Kategori Penilaian Ideal Motivasi Belajar

\begin{tabular}{cc}
\hline Kriteria & Skor \\
\hline Sangat Baik & $149,45<X$ \\
Baik & $120,65<X \leq 149,45$ \\
Cukup & $91,85<X \leq 120,65$ \\
Kurang & $63,05<X \leq 91,85$ \\
Sangat Kurang & $X \leq 63,05$ \\
\hline
\end{tabular}


Tabel 3. Kriteria Kategori Penilaian Ideal Kreativitas Belajar

\begin{tabular}{cc}
\hline Kriteria & Skor \\
\hline Sangat Baik & $37,75<\mathrm{X}$ \\
\hline Baik & $28,75<\mathrm{X} \leq 37,75$ \\
\hline Cukup & $19,75<\mathrm{X} \leq 28,75$ \\
\hline Kurang & $10,75<\mathrm{X} \leq 19,75$ \\
\hline Sangat Kurang & $\mathrm{X} \leq 10.75$ \\
\hline
\end{tabular}

Tabel 4. Kriteria Kategori Penilaian Ideal Tes Pemahaman Konsep

\begin{tabular}{cc}
\hline Kriteria & Skor \\
\hline Sangat Baik & $24,9<\mathrm{X}$ \\
\hline Baik & $19,3<\mathrm{X} \leq 24,9$ \\
\hline Cukup & $13,7<\mathrm{X} \leq 19,3$ \\
\hline Kurang & $8,1<\mathrm{X} \leq 13,7$ \\
\hline Sangat Kurang & $\mathrm{X} \leq 8,1$ \\
\hline
\end{tabular}

Setelah dilakukan analisis data, kemudian diperlukan adanya kriteria keberhasilan. Kriteria keberhasilan tindakan merupakan acuan dalam mempertimbangkan dan memberikan makna terhadap capaian tindakan. Keberhasilan pelaksanaan tindakan pada panelitian ini jika seluruh siswa sudah mencapai standar keberhasilan peningkatan motivasi belajar, kreativitas belajar, dan pemahaman konsep yaitu sekurang-kurangnya 70\% dari jumlah peserta didik (14 orang) telah mencapai kategori baik dari 5 skala kategori.

\section{Hasil Penelitian dan Pembahasan}

Sebelum penelitian dilaksanakan, terlebih dahulu dilakukan diskusi dengan guru untuk membahas permasalahan yang dihadapi selama pembelajaran. Hasil jaring pendapat dengan guru, dapat diketahui bahwa selama pembelajaran IPA motivasi belajar, kreativitas belajar dan pemahaman konsep Ilmu Pengetahuan Alam peserta didik kurang dapat berkembang karena penggunaan model pembelajaran yang kurang sesuai untuk mengembangkan aspek tersebut.

Diskusi yang dilakukan menjadi rujukan awal mencari solusi permasalahan yang paling tepat. Berdasarkan hasil dis- kusi guru dengan peneliti diketahui bahwa permasalahan yang dihadapi dalam pembelajaran berasal dari guru dan peserta didik.

Kreativitas belajar peseta didik dirasa masih kurang. Kurangnya kreativitas belajar peserta didik menyebabkan adanya permasalahan dalam pembelajaran. Disamping itu, guru juga merasa kurang efektifnya proses pembelajaran yang dilaksanakan selama ini karena pembelajaran dilaksanakan hanya dengan metode pendekatan konsep dan hanya mengembangkan aspek hafalan (remember). Pembelajaran dengan menggunakan metode pendekatan konsep akan membuat peserta didik pasif, akibatnya peserta didik kurang termotivasi untuk belajar dan kehilangan hampir setiap kesempatan untuk menjadi kreatif sehingga berdampak pada kurangnya pemahaman konsep Ilmu Pengetahuan Alam peserta didik.

Peserta didik cenderung dituntut untuk memberikan jawaban yang benar menurut guru dan kurang mendapat kesempatan untuk memberikan alternatif jawaban yang dapat menumbuhkan kreativitas. Guru belum menggunakan strategi yang tepat untuk memotivasi peserta didik untuk belajar dan mengembangkan aspek kreativitasnya. Oleh karena itu, guru perlu melakukan penyesuaian cara mengajar terhadap karakteristik mata pelajaran Ilmu Pengetahuan Alam, sehingga strategi yang digunakan dapat mengembangkan motivasi belajar, kreativitas belajar dan pemahaman konsep peserta didik.

Cara mengajar berkaitan dengan strategi pembelajaran yang digunakan guru dalam pembelajaran. Strategi pembelajaran yang dipilih dan digunakan guru hendaknya mampu mengembangkan kemampuan peserta didik tidak hanya pada aspek hafalan saja, tetapi juga mengembangkan motivasi belajar, kreativitas belajar dan pemahaman konsep peserta didik.

Kebermaknaan pembelajaran menggunakan Model Pembelajaran Berbasis Masalah yaitu adanya berbagai situasi bermasalah yang autentik dan bermakna 
sebagai batu loncatan untuk melakukan penyelidikan. Pembelajaran menggunakan model ini tidak dirancang untuk membantu guru dalam menyampaikan informasi dengan jumlah yang besar kepada peserta didik.

Pembelajaran menggunakan Model Pembelajaran Berbasis Masalah memiliki ciri yang khas, yaitu adanya pertanyaan dan masalah perangsang, fokus interdisipliner, investigasi autentik, adanya penemuan dan kolaborasi. Digunakannya pendekatan Sains Tekologi Masyarakat diharapkan peserta didik dapat dan mampu mencari, menganalisis, dan menerapkan konsep dan proses Ilmu Pengetahuan Alam dalam kehidupan sehari-hari.

Digunakannya Model Pembelajaran Berbasis Masalah diharapkan mampu menumbuhkan motivasi belajar dan pemecahan masalah secara kreatif sehingga mampu mengembangkan pemahaman konsep Ilmu Pengetahuan Alam peserta didik. Selain itu, penggunaan Model Pembelajaran Berbasis Masalah juga membantu peserta didik untuk bertindak pada situasi kehidupan yang nyata.

\section{Siklus I}

Pertemuan 1 dilaksanakan pada tanggal 5 April 2013. Pertemuan 1 terdiri dari dua tahap. Tahapan pembelajaran tersebut terdiri dari pemberian orientasi tentang permasalahan kepada peserta didik dan mengorganisasi peserta didik untuk meneliti. Selama pertemuan 1 guru mengkomunikasikan kepada peserta didik bahwa setiap kegiatan peserta didik di kelas diketahui guru. Kegiatan peserta didik dikelas dapat diketahui dengan memindai kelas secara keseluruhan dengan bantuan asisten pengajar. Saat pertemuan ini juga disampaikan kepada peserta didik bahwa peserta didik lebih terlibat dalam pelajaran dengan menunjukkan motivasi belajar, kreativitas belajar serta pemahaman konsep Ilmu Pengetahuan Alam yang tinggi.
Pertemuan 2 dilaksanakan pada tanggal 6 April 2013. Pertemuan 2 merupakan rangkaian dari pertemuan 1. Pertemuan 2 merupakan kegiatan memberikan bantuan kepada peserta didik untuk melakukan investigasi mandiri dan kelompok. Pada tahap ini peserta didik dibantu guru untuk menentukan sub-subtopik, tugastugas penyelidikan dan jadwal yang spesifik. Dalam melaksanakan penyelidikan, tugas perencanaannya yaitu membagi situasi bermasalah yang lebih umum menjadi sub-topik yang tepat, kemudian membagi peserta didik untuk memutuskan subtopik yang akan diselidiki.

Pertemuan 3 dilaksanakan pada tanggal 12 April 2013. Pertemuan 3 merupakan rangkaian dari pertemuan I dan II. Pertemuan 3 terdiri dari tahap mengembangkan, mempresentasikan hasil, mengevaluasi dan menganalisis proses pembelajaran.

Pertemuan 4 dilaksanakan pada tanggal 13 April 2013. Pertemuan 4 merupakan rangkaian dari pertemuan 3 . Pertemuan 4 berupa tahap pemberian test pemahaman konsep Ilmu Pengetahuan Alam.

Pada akhir siklus I, seluruh tim penelitian yang terdiri dari peneliti, guru dan asisten peneliti melakukan refleksi tentang keseluruhan proses tindakan siklus I. Hasil refleksi yaitu sebagai berikut: (1) ada 5 orang peserta didik dikelas yang kurang terlibat dalam kelompok selama pembelajaran Ilmu Pengetahuan Alam menggunakan Model Pembelajaran Berbasis Masalah (Problem Based Learning/PBL). Berdasarkan hasil wawancara, kesulitan mengikuti pembelajaran tersebut dikarenakan peserta didik tidak terbiasa bekerja sama dalam kelompok, namun peserta didik terbiasa belajar untuk bersaing mendapatkan posisi terbaik secara individu; (2) kurang adanya kepercayaan antara guru, peneliti dan peserta didik. Meskipun proses pembelajaran telah membaik, guru masih mengedepankan pembelajaran sesuai buku, sehingga keterkaitan materi dan lingkungan kurang diperhatikan; (3) motivasi belajar, kreativitas belajar dan pe- 
mahaman konsep IPA peserta didik selama siklus I belum mengalami peningkatan kriteria, yaitu masih dalam kategori cukup; (4) situasi pembelajaran belum menunjukkan terlaksananya penggunaan Model Pembelajaran Berbasis Masalah (Problem Based Learning/PBL) dan perhatian guru tidak merata, namun peserta didik merasa senang karena semua ide dan jawaban peserta didik dihargai sebagai perbedaan dalam memecahkan masalah; (5) berdasarkan hasil analisis data siklus I menunjukkan bahwa Model Pembelajaran Berbasis Masalah (Problem Based Learning/PBL) selama siklus I perlu direvisi untuk mengatasi kelemahan-kelemahannya tetapi masih mempertahankan unsur-unsur pokoknya.

\section{Siklus II}

Perencanaan tindakan siklus II merupakan lanjutan siklus I yaitu untuk memberikan pembelajaran Ilmu Pengetahuan Alam menggunakan PBLyang telah direvisi. Topik mata pelajaran masih sama seperti siklus I yaitu tentang masalahmasalah yang terkait dengan terjadinya bencana alam angin puting beliung, gunung meletus, tsunami, gempa bumi dan banjir serta mencari solusi dalam mencegah dan menanggulanginya.

Revisi model untuk siklus II menitikberatkan pada peran guru sebagai manajer didalam kelas. Untuk menjadi manajer kelas yang handal harus menguasai empat kegiatan yaitu "Withitness", overlapping activities, group focusing, dan movement managemement. Pembahasannya adalah sebagai berikut.

Withitness yang berarti mengkomunikasikan kepada peserta didik bahwa guru mengetahui setiap hal yang terjadi di kelas. Lebih memotivasi peserta didik agar lebih menunjukkan motivasi belajar dan kreativitas belajarnya, sehingga pemahaman konsepnya tercapai. Suatu usaha untuk memotivasi belajar peserta didik yaitu dengan memberikan bintang untuk menunjukkan tingkat motivasi belajar dan kreativitas belajarnya.
Overlapping activities berarti mengikuti dan mengawasi beberapa kegiatan sekaligus. Kegiatan ini dilakukan dengan memantau kegiatan pembelajaran hingga pembelajaran selesai.

Group focusing berarti menjaga agar sebanyak mungkin peserta didik terlibat dalam kegiatan kelas yaitu dengan memerintahkan kepada peserta didik untuk menyelesaikan tugas kelompok dengan berbagai alternatif jawaban, yaitu masingmasing anggota minimal memberikan 2 cara dalam menyelesaikan permasalahan yang terkait dengan bencana alam yang terjadi disekitar peserta didik yaitu tsunami, gempa bumi, gunung meletus, banjir dan angina putting beliung.

Movement managemement disebut juga manajemen perpindahan yaitu menjaga agar pelajaran bergerak dengan kecepatan yang tepat dan fleksibel dengan transisi dan variasi yang lancar. Langkah ini dilakukan dengan menyeragamkan materi yang sama tiap kelompok namun tiap kelompok menunjukkan penyelesaian yang berbeda. Kelompok yang telah selesai mengerjakan diperintahkan untuk menguji kembali kekuatan jawabannya bersama teman dalam kelompok dan asisten peneliti, sehingga situasi belajar tetap terjaga. Di akhir pembelajaran, siswa membuat karya tulis berupa artikel singkat tentang cara mencegah dan menanggulangi bencana alam disekitar peserta didik secara individu.

Siklus II ada kesamaan dengan siklus I, yaitu terdiri dari lima tahap. Tahap siklus II, yaitu pemberian orientasi tentang permasalahan kepada peserta didik, mengorganisasi peserta didik untuk meneliti, membantu investigasi mandiri dan kelompok, mengembangkan serta mempresentasikan hasil, menganalisis dan mengevaluasi proses.

Pelaksanaan PBL dalam pembelajaran Ilmu Pengetahuan Alam selama siklus II dilakukan dalam satu siklus yang terdiri dari 6 pertemuan (pertemuan 5-pertemuan 10). 
Pertemuan 5 dilaksanakan pada tanggal 19 April 2013. Pertemuan 5 terdiri dari dua tahap, yaitu pemberian orientasi tentang permasalahan kepada peserta didik dan mengorganisasi peserta didik untuk meneliti. Pada tahap ini guru memberikan penjelasan bahwa pembelajaran masih tetap seperti siklus I, yaitu menggunakan PBLdengan materi yang sama tiap kelompok untuk setiap pertemuannya. Selama pertemuan 5 guru mengkomunikasikan kepada peserta didik bahwa setiap kegiatan peserta didik dikelas diketahui guru. Kegiatan peserta didik dikelas dapat diketahui dengan memindai kelas secara keseluruhan dengan bantuan asisten pengajar. Saat pertemuan ini juga disampaikan kepada peserta didik bahwa peserta didik lebih terlibat dalam pelajaran dengan menunjukkan motivasi belajar, kreativitas belajar serta pemahaman konsep Ilmu Pengetahuan Alam yang tinggi. Jika ada kelompok yang telah menyelesaikan satu topik dalam satu pertemuan boleh mempelajari dan mengerjakan tugas selanjutnya sehingga dapat mengantisipasi peserta didik yang telah menyelesaikan satu topik dalam satu pertemuan mengganggu kelompok lain yang belum selesai.

Pertemuan 6, 7 dan 8 dilaksanakan pada tanggal 20, 22 dan 23 April 2013. Pertemuan 6, 7 dan 8 merupakan rangkaian dari pertemuan 5. Pertemuan ini memiliki kemiripaan dengan pertemuan 2, yaitu berupa kegiatan memberikan bantuan kepada peserta didik untuk melakukan investigasi mandiri dan kelompok. Topik yang akan dipelajari sama seperti pertemuan 2 . Masing masing topik dipelajari mulai pertemuan 6 hingga pertemuan 8 sebagai lanjutan dari pertemuan sebelumnya yaitu memahami konsep bencana alam gunung meletus, tsunami, gempa bumi, angin putting beliung dan bencana alam banjir.

Pertemuan 9 dilaksanakan pada tanggal 26 April 2013. Pertemuan 9 merupakan rangkaian dari pertemuan 8 . Pertemuan 9 merupakan proses mengembangkan, mempresentasikan hasil, mengevaluasi dan menganalisis proses pembelajaran.
Pertemuan 10 dilaksanakan pada tanggal 27 April 2013. Pertemuan 10 merupakan rangkaian dari pertemuan 9. Pertemuan 10 berupa tahap pemberian test pemahaman konsep Ilmu Pengetahuan Alam.

Pada akhir siklus II, seluruh tim penelitian yang terdiri dari peneliti, guru dan asisten peneliti melakukan kembali refleksi keseluruhan proses tindakan siklus II. Keseluruhan peserta didik telah menunjukkan perkembangan motivasi belajar yaitu ditunjukkan dari segi motivasi belajar, kreativitas belajar dan pemahaman konsep telah meningkat dari rata-rata cukup menjadi rata-rata baik. Dari segi motivasi belajar seluruh peserta didik telah mencapai kriteria ketuntasan minimal (KKM) yaitu seluruh peserta didik telah mencapai kriteria baik. Dari segi kreativitas belajar ada 7 orang peserta didik yang belum mencapai KKM yaitu masih berada pada kategori cukup, sehingga kriteria keberhasilan tindakan ditinjau dari aspek kreativitas belajar peserta didik belum tercapai. Dari segi pemahaman konsep Ilmu Pengetahuan Alam ada 7 orang peserta didik yang belum mencapai kriteria ketuntasan minimal, yaitu masih berada pada kategori cukup, sehingga kriteria keberhasilan tindakan ditinjau dari aspek pemahaman konsep Ilmu Pengetahuan Alam peserta didik belum tercapai.

Berdasarkan hasil analisis data perkembangan akademik dan wawancara, beberapa peserta didik yang belum mencapai kriteria ketuntasan minimalnya lebih cenderung kepada gaya kognitif fielddependent yang berlawanan dengan gaya kognitif field-independen. Peserta didik dengan gaya belajar field-dependent lebih mudah mempelajari pengetahuan sosial, mempunyai ingatan yang baik untuk informasi sosial, lebih mudah terpengaruh oleh kritik, perlu diajari cara menggunakan alat-alat bantu ingatan, cenderung menerima bahan pelajaran yang telah tersusun namun tidak mampu menyusunnya kembali serta perlu diajari memecahkan masalah. 
Siklus III

Perencanaan tindakan siklus III merupakan lanjutan siklus II, yaitu untuk memberikan pembelajaran Ilmu Pengetahuan Alam menggunakan PBLyang telah direvisi. Topik mata pelajaran masih sama seperti siklus III, yaitu tentang masalahmasalah yang terkait dengan terjadinya bencana alam angin puting beliung, gunung meletus, tsunami, gempa bumi dan banjir serta mencari solusi dalam mencegah dan menanggulanginya.

Revisi siklus III menitik beratkan pada perbedaan individu dalam kelompok. Perbedaan individu dapat dilihat dari gaya belajar masing-masing peserta didik. Gaya belajar peserta didik terdiri dari gaya belajar field-dependent dan gaya belajar fieldindependen.

Setiap gaya kognitif yang dimiliki peserta didik memiliki kelebihan dan kekurangan. Kedua jenis gaya kognitif ini tidak bisa dibandingkan melainkan perlu difasilitasi selama pembelajaran. Untuk lebih meningkatkan kreativitas belajar pada siklus II, peserta didik tersebut memerlukan cara belajar yang berbeda dengan teman yang lain yaitu:

Peserta didik yang memiliki gaya kognitif field-dependent dimasukkan ke dalam kelompok yang field-independent dengan harapan peserta didik yang memiliki gaya kognitif field-independent menjadi tutor sebaya.

Memunculkan ide kreatif dengan "memaksakan" suatu hubungan antara objek dan situasi yang dipermasalahkan dengan unsur-unsur lain untuk memunculkan gagasan-gagasan baru. Dalam siklus III yang akan dilaksanakan, proses "memaksakan" dilakukan dengan mencari hubungan kegiatan manusia dengan bencana alam yang terjadi serta mencari hubungan sebabakibat antar bencana alam yang terjadi. Bencana Alam yang dimaksud adalah gunung meletus, tsunami, gempa bumi, angin puting beliung dan banjir.

Menggunakan pendekatan morfologis dalam memecahkan masalah secara kreatif. Pendekatan morfologis bertujuan memecahkan masalah dengan mengkaji secara cermat bentuk dan struktur masalah. Dalam kegiatan siklus III yang akan dilakukan peserta didik adalah mencari solusi dalam menanggulangi bencana alam gunung meletus, tsunami, gempa bumi, angin puting beliung dan banjir. Langkah langkahnya dimulai dari dengan menentukan penyebab bencana, menentukan sifat bencana alam, kemudian mengkombinasikan sifat-sifat dan keterkaitan bencana alam untuk mendapatkan ide baru dalam menanggulangi terjadinya bencana alam.

Selama pertemuan III peserta didik diperbolehkan membuka internet sebagai literature tambahan. Dalam menggunakan internet, guru dan peneliti menggunakan beberapa kriteria pemilihan situs internet sebagai sumber belajar tambahan. Kriteria tersebut terdiri dari:

Situs internet yang digunakan bersifat motivasional bagi peserta didik, yaitu dengan memilih situs yang memuat animasi, ilustrasi grafis, real-time data, dan simulasi

Mengeksplorasi situs yang ditemukan peserta didik untuk disesuaikan dengan umur peserta didik.

Mendemonstrasikan cara mengakses situsdan mendskusikan jenis informasi yang dapat ditemukan dalam situs tersebut.

Menetapkan informasi penyebab bencana, menentukan sifat bencana alam, kemudian mengkombinasikan sifat-sifat dan keterkaitan bencana alam untuk mendapatkan ide baru dalam menanggulangi terjadinya bencana alam.

Memerintahkan kepada peserta didik untuk melaporkan situs temuannya dan mendiskusikan situs yang menawarkan informasi paling akurat dan dapat dipercaya.

Siklus III memiliki kesamaan dengan siklus II, yaitu terdiri dari lima tahap. Tahap siklus III adalah pemberian orientasi tentang permasalahan kepada peserta didik, mengorganisasi peserta didik untuk meneliti, membantu investigasi mandiri 
dan kelompok, mengembangkan serta mempresentasikan hasil, menganalisis dan mengevaluasi proses.

Pelaksanaan PBL dalam pembelajaran Ilmu Pengetahuan Alam selama siklus III dilakukan dalam satu siklus yang terdiri dari 6 pertemuan. Tiap pertemuan terdiri dari 2 jam pelajaran dengan waktu 90 menit.

Pelaksanan pembelajaran dengan penerapan PBL selama siklus III sama seperti siklus II terdiri atas lima tahapan. Tahapan tersebut terdiri dari pemberian orientasi tentang permasalahan kepada peserta didik, mengorganisasi peserta didik untuk meneliti, membantu investigasi mandiri dan kelompok, mengembangkan dan mempresentasikan hasil, serta menganalisis dan mengevaluasi proses.

Pertemuan 11 dilaksanakan pada tanggal 29 April 2013. Pertemuan 11 terdiri atas dua tahap yaitu, pemberian orientasi tentang permasalahan kepada peserta didik dan mengorganisasi peserta didik untuk meneliti. Pada tahap ini guru memberikan penjelasan bahwa pembelajaran masih tetap seperti siklus I dan II, yaitu menggunakan PBL dengan materi yang sama tiap kelompok untuk setiap pertemuannya. Selama pertemuan 11 guru mengkomunikasikan kepada peserta didik bahwa setiap kegiatan peserta didik dikelas diketahui guru. Kegiatan peserta didik dikelas dapat diketahui dengan memindai kelas secara keseluruhan dengan bantuan asisten pengajar. Saat pertemuan ini juga disampaikan kepada peserta didik bahwa peserta didik lebih terlibat dalam pelajaran dengan menunjukkan motivasi belajar, kreativitas belajar serta pemahaman konsep Ilmu Pengetahuan Alam yang tinggi. Mengkaji hasil analisis data siklus II dan wawancara dengan peserta didik dan revisi model untuk siklus II, peserta didik dikelompokkan ulang dengan menyusun kelompok yang beragam berdasarkan gaya kognitifnya. Harapan disusunnya kelompok yang beragam gaya kognitifnya agar kelompok kelompok menjadi seimbang perkembangannya. Peserta didik yang me- miliki gaya kognitif field-dependent diacak dan dimasukkan kedalam kelompok yang field-independent dengan harapan peserta didik yang memiliki gaya kognitif fieldindependent menjadi tutor sebaya selama pembelajaran siklus III.

Pertemuan 12, 13, dan 14 dilaksanakan pada tanggal 30 April, 3 dan 4 Mei 2013. Pertemuan 12, 13, dan 14 merupakan rangkaian dari pertemuan 11. Pertemuan ini memiliki kemiripaan dengan pertemuan 2 dan 5 yaitu berupa kegiatan memberikan bantuan kepada peserta didik untuk melakukan investigasi mandiri dan kelompok. Topik yang akan dipelajari sama seperti pertemuan 2. Masing masing topik dipelajari mulai pertemuan 12 hingga pertemuan 14 sebagai lanjutan dari pertemuan sebelumnya yaitu memahami konsep dengan cara mencari hubungan terjadinya bencana alam gempa bumi, gunung meletus, tsunami, banjir, tanah longsor dan angin puting beliung.

Pertemuan 15 dilaksanakan pada tanggal 6 Mei 2013. Pertemuan 15 merupakan rangkaian dari pertemuan 14. Pertemuan 15 merupakan proses mengembangkan dan mempresentasikan hasil, mengevaluasi dan menganalisis proses pembelajaran.

Pertemuan 16 dilaksanakan pada tanggal 7 Mei 2013. Pertemuan 16 merupakan rangkaian dari pertemuan 15. Pertemuan 16 berupa tahap pemberian test pemahaman konsep Ilmu Pengetahuan Alam.

Pada akhir siklus III, seluruh tim penelitian yang terdiri dari peneliti, guru dan asisten peneliti melakukan kembali refleksi keseluruhan proses tindakan siklus III. Hasil refleksi adalah keseluruhan peserta didik telah menunjukkan perkembangan motivasi belajar, kreativitas belajar dan pemahaman konsep telah melebihi KKM (Kriteria Ketuntasan Minimal). Hasil tindakan siklus III menunjukkan bahwa: (1) Jumlah peserta didik yang memiliki motivasi belajar kategori sangat baik berjumlah 20 orang; (2) Jumlah peserta didik yang memiliki kreativitas belajar kategori sangat baik berjumlah 20 orang. Jumlah 
peserta didik yang memiliki pemahaman konsep sangat baik berjumlah 10 orang dan kategori baik berjumlah 10 orang.

Peningkatan motivasi belajar IPA peserta didik kelas V SDN Nomporejo Kecamatan Galur Kabupaten Kulon Progo pada Gambar 2.

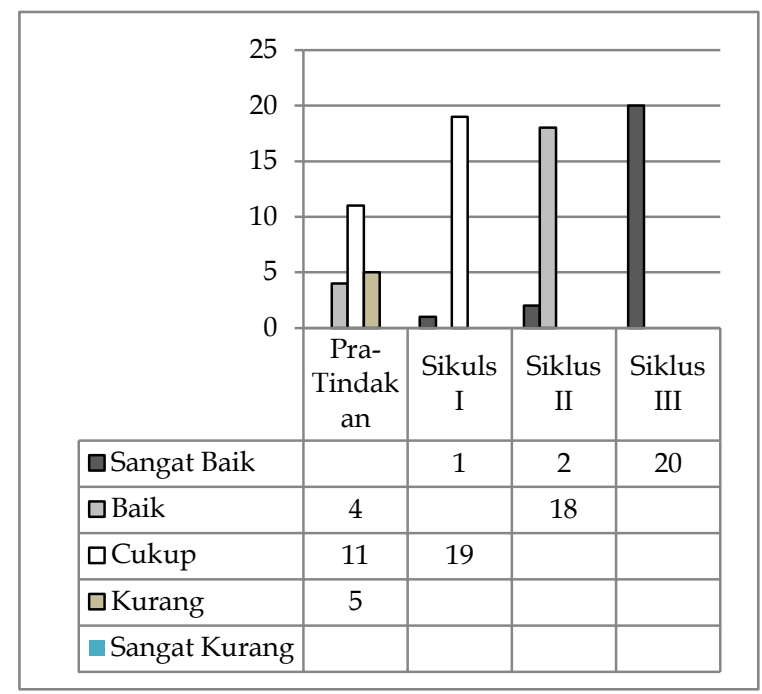

Gambar 2. Diagram Batang Peningkatan Skor Motivasi Belajar IPA Peserta Didik Kelas V SDN Nomporejo

Berdasarkan diagram batang peningkatan kriteria skor motivasi belajar IPA peserta didik kelas V SDN Nomporejo Kecamatan Galur Kabupaten Kulon Progo dapat dideskripsikan skor motivasi belajar peserta didik mulai dari siklus I, siklus II, dan siklus III. Selama siklus I diperoleh hasil bahwa peserta didik kategori sangat baik berjumlah 1 orang dan kategori cukup berjumlah 19 orang dengan perolehan skor rata-rata sedikit meningkat dari 106,25 menjadi 110,7 kriteria skor cukup. Selama siklus II diperoleh hasil bahwa peserta didik berkategori sangat baik berjumlah 2 orang dan kategori baik berjumlah 18 orang dengan perolehan skor rata-rata meningkat dari 110,7 menjadi 136,6 ratarata kriteria skor baik. Selama siklus III diperoleh hasil bahwa peserta didik berkategori sangat baik berjumlah 20 orang dengan perolehan skor rata-rata semakin meningkat dari 136,6 menjadi 157,9 ratarata kriteria skor sangat baik.
Peningkatan kreativitas belajar IPA peserta didik kelas V SDN Nomporejo Kecamatan Galur Kabupaten Kulon Progo pada Gambar 3.

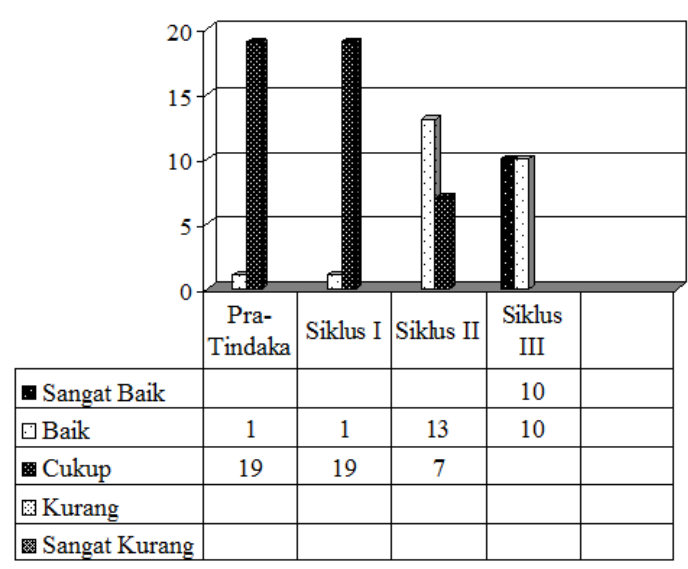

\section{Gambar 3. Diagram Batang Peningkatan Skor Kreativitas Belajar IPA Peserta didik Kelas V SDN Nomporejo}

Berdasarkan diagram batang peningkatan kriteria skor ideal kreativitas belajar IPA peserta didik kelas V SDN Nomporejo Kecamatan Galur Kabupaten Kulon Progo dapat dideskripsikan skor kreativitas belajar peserta didik mulai dari siklus I, siklus II, dan siklus III. Selama siklus I diperoleh hasil bahwa belum ada peningkatan selama tindakan, yaitu peserta didik berkategori sangat baik berjumlah 1 orang dan kategori cukup berjumlah 19 orang. Perolehan skor sebesar 24,4 dengan rata-rata kriteria skor cukup. Selama siklus II diperoleh hasil bahwa peserta didik berkategori sangat baik berjumlah 13 orang dan kategori cukup berjumlah 7 orang. Perolehan skor rata-rata meningkat dari 24,4 menjadi 28,8 dengan kriteria skor baik. Jumlah peserta didik yang telah mencapai KKM berjumlah 13 orang. Selama siklus III diperoleh hasil bahwa peserta didik berkategori sangat baik berjumlah 10 orang dan berkategori baik berjumlah 10 orang. Perolehan skor rata-rata semakin meningkat dari 28,8 menjadi 42,6 dengan kriteria skor sangat baik.

Peningkatan hasil Tes pemahaman konsep IPA peserta didik kelas V SDN 
Nomporejo Kecamatan Galur Kabupaten Kulon Progo pada Gambar 4.

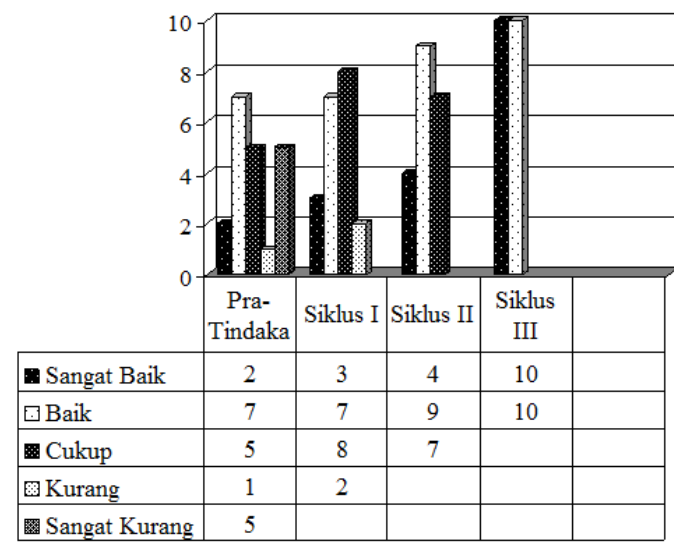

Gambar 4. Diagram Batang Peningkatan Skor Tes Pemahaman Konsep IPA Peserta Didik Kelas V SDN Nomporejo

Berdasarkan diagram batang peningkatan kriteria skor tes pemahaman konsep IPA peserta didik kelas V SDN Nomporejo Kecamatan Galur Kabupaten Kulon Progo dapat dideskripsikan skor tes pemahaman konsep IPA peserta didik mulai dari siklus I, siklus II, dan siklus III.

Selama siklus I diperoleh hasil bahwa peserta didik berkategori sangat baik berjumlah 3 orang, kategori baik berjumlah 7 orang, kategori cukup ber-jumlah 8 orang dan kategori kurang berjumlah 2 orang. Perolehan skor rata-rata sedikit meningkat dari 16,5 menjadi 18,9 dengan kriteria skor cukup. Selama siklus II diperoleh hasil bahwa peserta didik berkategori sangat baik berjumlah 4 orang, kategori baik berjumlah 9 orang dan kategori cukup berjumlah 7 orang. Perolehan skor rata-rata meningkat dari 18,9 menjadi 20,3 dengan kriteria skor baik. Selama siklus III diperoleh hasil bahwa peserta didik berkategori sangat baik berjumlah 10 orang dan peserta didik yang berkategori baik berjumlah 10 orang. Perolehan skor rata-rata semakin meningkat dari 20,3 menjadi 23,65 dengan kriteria skor baik.

Keberhasilan tindakan terhadap motivasi belajar, kreativitas belajar dan tes pemahaman konsep IPA peserta didik kelas V SDN Nomporejo Siklus I, Siklus II, Siklus III pada Gambar 5.

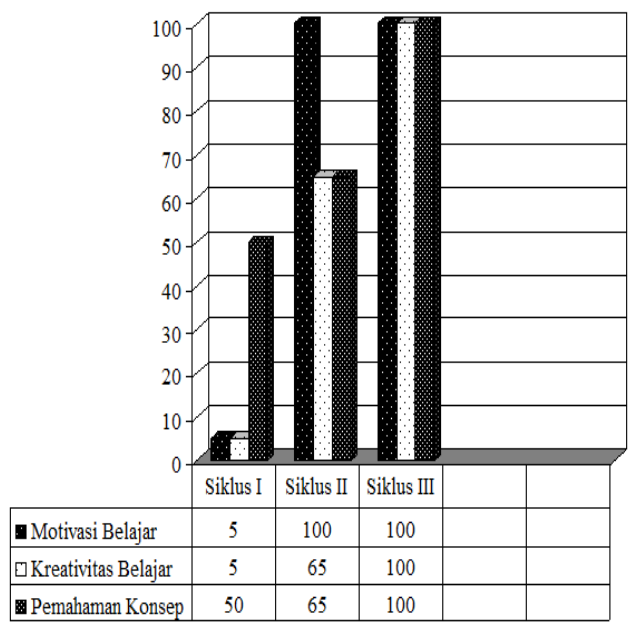

Gambar 5. Diagram Batang Persentase Keberhasilan Tindakan terhadap Motivasi Belajar,

Kreativitas Belajar dan Pemahaman Konsep IPA Peserta didik Kelas V SDN Nomporejo

Berdasarkan diagram batang persentase keberhasilan tindakan terhadap motivasi belajar, kreativitas belajar dan pemahaman konsep IPA peserta didik kelas V SDN Nomporejo Kecamatan Galur Kabupaten Kulon Progo Siklus I, Siklus II, dan Siklus III dapat dideskripsikan tingkat keberhasilan tindakan. Persentase keberhasilan tindakan siklus I terhadap motivasi belajar peserta didik sebesar 5\%. Persentase keberhasilan tindakan siklus II dan III terhadap motivasi belajar peserta didik sebesar $100 \%$. Persentase keberhasilan tindakan siklus I terhadap kreativitas belajar peserta ddik sebesar 5\%. Persentase keberhasilan tindakan siklus II terhadap kreativitas belajar peserta didik sebesar 65\%. Persentase keberhasilan tindakan siklus III terhadap kreativitas belajar peserta didik sebesar $100 \%$. Persentase keberhasilan tindakan siklus I terhadap pemahaman konsep peserta didik sebesar $50 \%$. Persentase keberhasilan tindakan siklus II terhadap pemahaman konsep peserta didik sebesar $65 \%$. Persentase keberhasilan tindakan sik- 
lus III terhadap pemahaman konsep peserta didik sebesar $100 \%$.

Keterbatasan penelitian dengan judul Implementasi Model Pembelajaran Berbasis Masalah untuk Meningkatkan Motivasi, Kreativitas dan Pemahaman Konsep Ilmu Pengetahuan Alam Peserta Didik Kelas V SD Negeri Nomporejo Kecamatan Galur Kabupaten Kulon Progo yaitu sebagai berikut: (1) adanya bias terhadap model pembelajaran berbasis masalah untuk meningkatkan motivasi, kreativitas dan pemahaman konsep jika diterapkan pada subjek dan setting yang berbeda; (2) subjek maupun setting penelitian hanya terbatas pada penerapan satu model pembelajaran, yaitu Model Pembelajaran Berbasis Masalah; (3) waktu yang diberikan kepada pihak sekolah terbatas karena ada kegiatan tryout persiapan UAN, uji coba UAS BN, dan test tengah semester, sehingga penelitian yang dilakukan kurang optimal; (4) guru dan peneliti masih kesulitan untuk secara langsung menghadirkan semua objek permasalahan yang dipecahkan; (5) kondisi kelas menjadi tidak terkendali jika guru keluar ruangan.

\section{Simpulan dan Saran}

Simpulan

Digunakannya PBL dapat meningkatkan motivasi belajar Ilmu Pengetahuan Alam peserta didik kelas V SD Negeri Nomporejo. Selama siklus I, peserta didik berkategori sangat baik berjumlah 1 orang dan kategori cukup berjumlah 19 orang dengan rata-rata skor sedikit meningkat dari 106,25 menjadi 110,7 kriteria skor cukup. Selama siklus II, peserta didik kategori sangat baik berjumlah 2 orang dan kategori baik berjumlah 18 orang dengan rata-rata skor meningkat dari 110,7 menjadi 136,6 kriteria skor baik. Selama Siklus III peserta didik berkategori sangat baik berjumlah 20 orang dengan skor semakin meningkat dari rata-rata skor 136,6 menjadi 157,95 kriteria skor sangat baik. Persentase keberhasilan tindakan siklus I terhadap motivasi belajar peserta didik sebesar 5\% dan keberhasilan tindakan siklus II dan III sebesar $100 \%$.

Digunakannya PBL dapat meningkatkan kreativitas belajar Ilmu Pengetahuan Alam peserta didik kelas V SD Negeri Nomporejo. Selama siklus I, peserta didik berkategori sangat baik berjumlah 1 orang dan kategori cukup berjumlah 19 orang dengan rata-rata skor 24,4 kriteria skor cukup. Selama siklus II peserta didik berkategori sangat baik berjumlah 13 orang dan kategori cukup berjumlah 7 orang dengan rata-rata skor meningkat dari 24,4 menjadi 28,8 kriteria skor baik. Selama siklus III, peserta didik berkategori sangat baik berjumlah 10 orang dan kategori baik berjumlah 10 orang dengan rata-rata skor semakin meningkat dari 28,8 menjadi 42,6 kriteria skor sangat baik. Persentase keberhasilan tindakan siklus I sebesar $5 \%$, persentase keberhasilan tindakan siklus II sebesar $65 \%$, dan persentase keberhasilan tindakan siklus III sebesar $100 \%$.

Digunakannya PBL dapat meningkatkan pemahaman konsep Ilmu Pengetahuan Alam peserta didik kelas V SD Negeri Nomporejo. Selama siklus I I, peserta didik berkategori sangat baik berjumlah 3 orang, kategori baik berjumlah 7 orang, kategori cukup berjumlah 8 orang dan kategori kurang berjumlah 2 orang dengan rata-rata skor sedikit meningkat dari 16,5 menjadi 18,9 dengan kriteria skor cukup. Selama siklus II, peserta didik berkategori sangat baik berjumlah 4 orang, kategori baik berjumlah 9 orang dan kategori cukup berjumlah 7 orang dengan ratarata skor meningkat dari 18,9 menjadi 20,3 kriteria skor baik. Selama siklus III, peserta didik berkategori sangat baik berjumlah 10 orang dan kategori baik berjumlah 10 orang dengan rata-rata skor semakin meningkat dari 20,3 menjadi 23,65 kriteria skor baik. Persentase keberhasilan tindakan siklus I sebesar $50 \%$, persentase keberhasilan tindakan siklus II sebesar $65 \%$ dan persentase keberhasilan tindakan siklus III sebesar $100 \%$. 
Saran

Saran dalam penelitian ini dapat ditinjau dari segi input, proses dan output. Dari segi input pembelajaran, dapat mengoptimalkan input dengan mendesain pembelajaran yang sesuai dengan karakteristik dan kebutuhan peserta didik. Dari segi proses pembelajaran, guru hendaknya menggunakan model pembelajran yang sesuai dengan karakteristik mata pelajaran serta menggunakan metode pembelajaran yang berpusat pada peserta didik untuk memfasilitasi perbedaan peserta didik. Dari segi output pembelajaran, untuk mengetahui pemahaman konsep peserta didik, maka perlu dilakukan pre-test dan post-test secara berkala, sehingga dapat segera diketahui tingkat pemahaman konsep peserta didik pada suatu materi pelajaran.

\section{Daftar Pustaka}

Arends, R.I. (2007). Learning to teach. New York: McGraw-Hill.

Badan Standar Nasional Pendidikan. (2006). Standar Isi untuk Satuan
Pendidikan Dasar dan Menengah. Jakarta: BSNP.

Budiningsih, A. (2005). Belajar dan pembelajaran. Jakarta: Rineka Cipta.

Budiningsih, A. (2004). Karakteristik siswa. Yogyakarta: Fakultas Ilmu Pendidikan Universitas Negeri Yogyakarta.

Kemmis, S., \& McTaggart, R. (2000). Participatory action research. CA: Sage.

Munandar, U. (1990). Mengembangkan bakat dan kreativitas anak sekolah. Jakarta: PT Gramedia.

Santrock, J.W. (2008). Education psycology part 1 ( $\left.2^{\text {nd }} e d.\right)$. New York: McGrawHill.

Sugiyono \& Wibowo, E. (2003). Statistik untuk penelitian. Bandung: Alfabeta.

Sugiyono. (2012). Metode penelitian kombinasi (mixed methods). Bandung: Alfabeta.

Sumitro. (2004). Pengantar ilmu pendidikan. Yogyakarta: Fakultas Ilmu Pendidikan Universitas Negeri Yogyakarta. 